Article

\title{
The Impact of Fungicides, Plasma, UV-Additives and Weathering on the Adhesion Strength of Acrylic and Alkyd Coatings to the Norway Spruce Wood
}

\author{
Ladislav Reinprecht ${ }^{1, * \mathbb{D}}$, Radovan Tiňo ${ }^{2}$ a and Marek Šomšák ${ }^{3}$ \\ 1 Department of Wood Technology, Faculty of Wood Sciences and Technology, Technical University in Zvolen, \\ T. G. Masaryka 24, SK-960 01 Zvolen, Slovakia \\ 2 Faculty of Chemical and Food Technology, Slovak Technical University, Radlinského 9, \\ SK-812 37 Bratislava, Slovakia; radko.tino@stuba.sk \\ 3 Agrotechnical Secondary Vocational School, SK-045 01 Moldava nad Bodvou, Slovakia; \\ somsak.marek@gmail.com \\ * Correspondence: reinprecht@tuzvo.sk
}

Received: 28 October 2020; Accepted: 16 November 2020; Published: 19 November 2020

\begin{abstract}
The adhesion strength between the transparent acrylic or alkyd coatings and the Norway spruce (Picea abies Karst L.) wood was determined by EN ISO 4624 and analyzed concerning four variables: (a) fungicidal pre-treatment of wood with boric acid or benzalkonium chloride, (b) cold plasma modification of wood surfaces, (c) presence of hindered amine light stabilizer (HALS) or hydroxyphenyl-benzotriazoles (BTZ) in the role of UV-additives in coatings, and (d) weathering of coated wood-lasting 1 week in Xenotest by a modified EN 927-6, or 14, 28 and 42 weeks outdoors at $45^{\circ}$ by EN 927-3. In the un-weathered state, the adhesion strength was positively affected by the initial plasma modification of wood surfaces, more evident with the application of acrylic water-borne coatings. On the contrary, the adhesion strength was not influenced by the fungicidal pre-treatment of wood and by the UV-additive's presence in coatings. The adhesion was negatively affected by weathering-exponentially outdoor-irrespective of the fungicidal pre-treatment of wood, the plasma modification of wood surfaces, the coating type, and the presence of UV-additive in coatings.
\end{abstract}

Keywords: spruce wood; fungicides; plasma; coatings; UV-additives; weathering; adhesion

\section{Introduction}

In outdoor expositions, unprotected wood surfaces are easily attacked by sunlight. The penetration depth of UV-radiation into wood is approximately 75 micrometers and of the visible light 125-500 micrometers [1]. However, free radicals created from the initially photodegraded lignin and hemicellulose macromolecules can further damage wood components up to a depth of approximately 2000 micrometers. Surfaces of wet wood are synchronously susceptible to deterioration processes by bacteria and molds causing color defects and also health problems for people [2].

Coatings recommended for wooden products that are exposed exteriorly, e.g., windows, pergolas, façades, or terrace boards, must protect them against sunlight, water, and microorganisms. This means that the commercial acrylic, alkyd, polyurethane, epoxy, or other coating types should contain suitable additives—-pigments, UV-additives, hydrophobic substances, and biocides.

The pigments and UV-additives absorb sunlight, decrease destructive effects of sunlight, or inhibit its transfer through coatings into wood [3-6]. The hydrophobic substances, e.g., natural and synthetic waxes, increase a contact angle between the coated wood and the water drops and decrease the penetration of water through the coating into wood [7]. The environmentally acceptable bactericides and fungicides protect coatings and wood against bio-deteriorations [8]. 
The transparent, unpigmented coatings used in exteriors should contain effective UV-additives that preserve the macromolecules of coatings from radical depolymerization reactions leading to their destruction and protect the painted wood from color changes and other aesthetical defects [9]. Today, the following substances are applied as UV-additives in coatings: (a) UV absorbers such as 2-hydroxyphenyl-s-triazines [5,10], 2-(2-hydroxyphenyl)-benzotriazoles (BTZ) [3,5], or 2-hydroxyphenyl-benzophenones [11], (b) UV blockers-screeners such as zinc oxide (ZnO), titanium dioxide $\left(\mathrm{TiO}_{2}\right)$ or cesium dioxide $\left(\mathrm{CsO}_{2}\right)$, usually used in the form of nanoparticles [3,5,6,12-14], (c) hindered amine light stabilizers (HALS) $[15,16]$, (d) sometimes also with other photo-stabilization mechanisms, for example, imidized nanoparticles which also have a hydrophobic effect [17], or lignin stabilizers such as succinic anhydride in combination with epoxidized soybean oil [11]. Unfortunately, the efficiency of UV-additives in coatings does not always last long-term [18,19].

Coatings for wood products exposed outdoors are increasingly modified with environmentally acceptable organic bactericides and fungicides, for example 3-iodo-2-propinyl-N-butyl-carbamate (IPBC), propiconazole, tebuconazole, or quaternary ammonium compounds (QACs), or less frequently with inorganic biocides, for example nano $\mathrm{ZnO}$, or nano silver $[7,8,20,21]$. These biocides, as well as other ones, can also be used for wood pre-treatment before the application of coatings [22].

The functional, protective, and decorative properties of coatings used for the treatment of wood surfaces exposed exteriorly should be sufficient and long-term [23]. However, the adhesion strength between coatings and wood surfaces usually worsens over time in relation to: (1) the type and intensity of environmental factors, i.e., the sun-irradiation, water precipitation, wind, emission of carbon blacks and aggressive chemicals, (2) the presence of bacteria, molds or other pests, (3) the used wood species with specific surface characteristics and its physical, chemical or biological pre-treatments before painting with coating, and (4) the used coating type, and the technology of its application.

Individual wood species have specific surface characteristics-wettability, free surface energy, porosity, roughness, $\mathrm{pH}$-value, resistance to bacteria, molds, decaying fungi, etc. [24-29]. All surface characteristics of wood are directly connected with its geometrical, morphological, anatomical, and molecular structure [30]. Differences in the wood surface texture of various wood species or of specimens of the same wood species are given by (a) the geometrical level, such as the radial or tangential surface, knots, roughness influenced by machining, etc., (b) the morphological and anatomical levels, such as the diameter of cell elements "fibers, vessels, rays, ... " and their lumens, etc., and (c) the molecular level, such as the type and amount of hydroxyl and other polar functional groups, crystallinity of cellulose, polarity of lignin-polysaccharide components and various extractives, migration of extractives, etc. The surface texture of wood significantly influences the wettability and penetration processes of liquid coatings into wood as well as the adhesion of created coating films to wood.

However, the wood species, its roughness, and other surface characteristics are not always the most important factors that affect the adhesion strength, as the role of the coating, and similarly of the glue, is usually more important [31,32]. As already mentioned in the previous paragraphs, pigmented coatings are preferentially recommended for exterior usage, while the transparent coatings can only be used after adjusting them with effective and stable UV-additives, hydrophobic and antimicrobial substances. Kúdela and Liptáková [33] and several other researchers identified the "coating-wood" interface as a very important parameter for overall stability and the lifetime of coatings. The adhesion strength between coatings and wood surfaces can be improved by wood pre-treatment with chemical penetrating systems, as well as by wood modification with specific physical methods.

Modification of wood surfaces with plasma is a well-known physical method for their activation before the application of coatings or glues [34-37]. The plasma barrier discharge serves to activate wood surfaces prior to the application of coatings to ensure a higher adhesion strength and increase the service lifetime of coated or glued woods. Plasma can improve the surface properties of wood, wooden composites, and some other materials $[37,38]$. Plasma forms a thin protection layer on a wooden 
surface, which is effective against the sun, water, and biological influences. Several experiments have shown that plasma can change the chemical composition of wood surfaces, thereby also changing their wettability together with improving the adhesion strength of coatings and glues to wood [35,37-44]. The plasma discharge in wood surfaces activates polysaccharides, lignin and extractives and in the presence of air generates new hydroxyl, carbonyl, carboxyl, peroxide or ether functional groups and radicals, and simultaneously liberates reactive intermediates, such as $\mathrm{O}_{2}{ }^{+},{ }^{1} \mathrm{O}_{2}, \mathrm{O}_{3}, \mathrm{O}^{+}$, ionized ozone, free electrons, $\mathrm{N}, \mathrm{CO}_{2}$, excited states of $\mathrm{N}_{2}$, etc. [37,45]. These substances react with the wood surface and provide a convenient resource for its activation and purposeful alteration of its wettability [46].

In presence of ozone, wood components are transformed into smaller and also more polar molecules. Thus, newly formed compounds in wood surfaces can form new chemical bonds with the surrounding lignin-polysaccharide components of wood and also with molecules of the used coating system. Following this, an assumption can be pronounced-newly bonded joints in the plasma modified wood will ensure better adhesion of the coating to its surface with a positive effect on the final quality and lifetime of the wooden product. In addition, the surface modification of wood by plasma carried out in the air, with the production of ozone, is an effective sterilizing method for the killing of bacteria or molds [34,42].

In the last few years, the cold low-temperature plasma (LTP) is increasingly used for the surface modification of wood, wood composites, wood-plastic composites, and other technical materials, because the degrading thermal effect of the cold plasma on these materials is neglected [38,47]. LTP does not require high temperatures that are needed in the preparation of ThermoWoods (thermally modified wood at $180-220^{\circ} \mathrm{C}$ ), and it is effective without the presence of activating chemical agents that otherwise maximize the benefits of subsequently applied natural or synthetic coatings [48]. In addition, the reaction time of LTP with wood components is relatively short, usually only from a few seconds to several minutes, additionally, the process is performed in a dry environment, and no by-products are produced. The surface of the plasma modified wood becomes more polar, more hydrophilic, and with better wettability with water-based coating systems, for example with acrylic water dispersions. However, gradually, over a period of time, usually after 7 to 30 days of exposure to plasma, the wood surfaces become chemically inert and even more hydrophobic [45]. The hydrophobic character of pinewood surface was also achieved by Moghaddam et al. [49], who created a thin transparent superhydrophobic layer, consisting of nanoparticulate $\mathrm{TiO}_{2}$ and the following deposition of plasma polymerized organic substances, effective for controlling its wettability and water repellency.

Generally, the permanent quality of painted wood is connected with its color stability, resistance to the creation of cracks, to thickness reduction and to biological attacks, as well as the good and long-term adhesion strength of the coating system with the wood surface. In exterior exposures, the durability of wood surfaces painted with transparent coatings are often limited to just their adhesion strength to wood substrate. Adhesion of coatings to wood is commonly susceptible to weathering conditions, but less information exists about the effect of wood pre-treatment with fungicides and plasma and also about the presence of UV-additives in coatings. The Norway spruce is a common and very important wood species, mainly in Central Europe, used for industrial and building structures, bridges, furniture, musical instruments, sport equipment and other uses. From this point of view, research aimed at improving its surface properties was performed in this work.

The basic aim of this work was to examine changes in the adhesion strength between transparent acrylic and alkyd coatings and the Norway spruce wood due to weathering, in parallel evaluating some other impacts, including the presence of HALS or BTZ UV-additives in coatings, the fungicidal pre-treatment of wood with boric acid or benzalkonium chloride and the plasma modification of wood surfaces. 


\section{Materials and Methods}

\subsection{Wood}

Top surfaces of the naturally dried and planed Norway spruce (Picea abies Karst L.) boards were gradually ground along the grain on a belt sander with 80 grit and 120 grit sandpapers, and then freed from wooden dust with compressed air. Following this, the samples: (a) with a dimension of $80 \mathrm{~mm} \times 45 \mathrm{~mm} \times 8 \mathrm{~mm}$ (axial $\times$ radial $\times$ tangential) for the artificial weathering test, and (b) with a dimension of $375 \mathrm{~mm} \times 78 \mathrm{~mm} \times 20 \mathrm{~mm}$ (axial $\times$ radial $\times$ tangential) for the outdoor weathering test were prepared from boards. Selected samples, i.e., without biological damages, juvenile wood, and growth inhomogeneities, were conditioned at a temperature of $20 \pm 2{ }^{\circ} \mathrm{C}$ and a relative air humidity of $65 \pm 5 \%$ achieving their equilibrium moisture content of $12 \pm 2 \%$. The density of the spruce samples used in the experiment ranged from 450 to $475 \mathrm{~kg} \cdot \mathrm{m}^{-3}$. The roughness parameters $R a$ (arithmetic mean deviation) and $R z$ (arithmetic mean of the heights and depressions of the profile at the basic length), determined for twenty selected samples perpendicular to the grain using the profilometer Surfcom 130A (Carl Zeiss, Jena, Germany) in accordance with the standard EN ISO 4287 [50], ranged in the intervals of 6.04-7.42 $\mu \mathrm{m}$ and 50.2-57.6 $\mu \mathrm{m}$.

\subsection{Fungicidal Pre-Treatment of Wood}

For the fungicidal pre-treatment of spruce samples we used $2 \mathrm{wt}$ \% water solutions of boric acid $\left(\mathrm{H}_{3} \mathrm{BO}_{3}\right)$ (Funchem, Czech Republic) and benzalkonium chloride (BAC) belonging to QACs, synonym: alkylbenzyldimethylammonium chloride (Sigma Aldrich, Germany). Parameters of the soaking technology were as follows: a pressure of $100 \mathrm{kPa}$, a temperature of $30^{\circ} \mathrm{C}$, and an immersion time of $10 \mathrm{~min}$. Spruce samples pre-treated with fungicides were then again conditioned achieving their equilibrium moisture content of $12 \pm 2 \%$.

\subsection{Plasma Modification of Wood Surfaces}

The top surfaces of spruce samples were modified with atmospheric low-temperature/cold plasma in laboratories of the Slovak Technical University in Bratislava, Slovakia, using the "Atmospheric Discharge with Runway Electrons" (ADRE) device (EST, Tomsk, Russia). The plasma modification was performed for one half of each group of spruce samples-the native, $\mathrm{H}_{3} \mathrm{BO}_{3}$ pre-treated, and $\mathrm{BAC}$ pre-treated. The following operating conditions were set in the ADRE device: a power of $1.4 \mathrm{~kW}$, a frequency of $2000 \mathrm{~Hz}$, and an exposure time of $60 \mathrm{~s}$ (Figure 1).

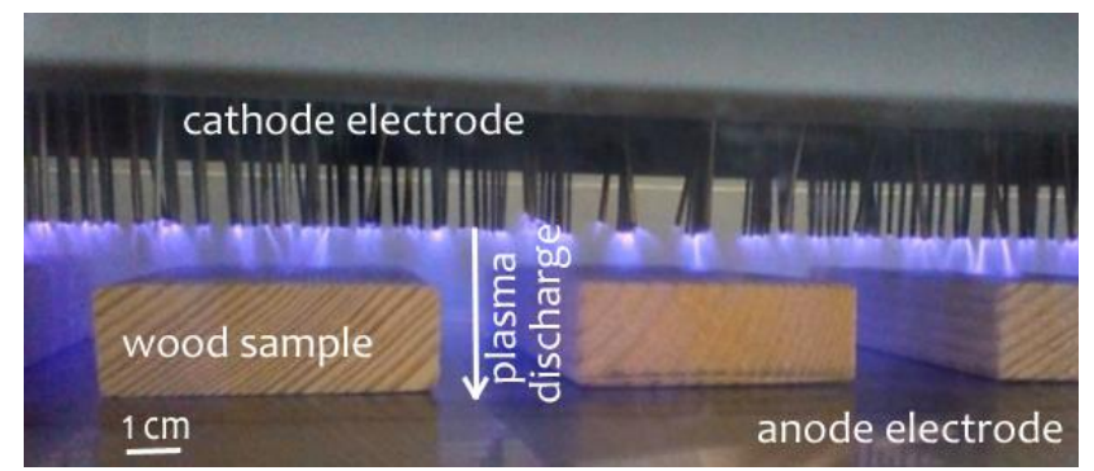

Figure 1. Plasma modification of the top surfaces of spruce samples in the "Atmospheric Discharge with Runway Electrons" (ADRE) device.

The initial contact angles $\gamma_{0}$ of redistilled water with the top surfaces of the natural (fungicidally un-pre-treated) spruce samples were measured using the SEE System (Advex Instruments, Brno, Czech Republic) instrument, always for 10 replicates. The contact angle $\gamma_{0}$ for the native unmodified spruce samples was $55^{\circ} \pm 2.3^{\circ}$, and after the plasma modification it actually decreased to 
$13^{\circ} \pm 1.6^{\circ}$ as a result of the polar functional groups created in wood surfaces; however, after $24 \mathrm{~h}$, it partly increased to $20^{\circ} \pm 5.5^{\circ}$ and after $72 \mathrm{~h}$ even to $35^{\circ} \pm 6.5^{\circ}$ — these tendencies are in accordance with [45].

\subsection{Coatings and $U V$-additives}

In experiment two types of transparent coatings synthesized by the company Chemolak Smolenice Ltd., Slovakia were used: (a) the acrylic water dispersion with a solids content of $28.6 \%$ (density $1.05 \mathrm{~g} / \mathrm{cm}^{3}$ ), and (b) the alkyd in non-aromatic petrol with a solids content of $54.9 \%$ (density $0.91 \mathrm{~g} / \mathrm{cm}^{3}$ ). Two UV-additive types were added into these coatings in the amounts of $0,0.25,0.5$, and $1 \mathrm{wt} . \%$ : (a) the hindered amine light stabilizer (HALS) containing bis-(1,2,2,6,6-tetramethyl-4-piperidinyl)sebacate and methyl-(1,2,2,6,6,-tetramethyl-4-piperidinyl) sebacate: commercial product EVERSORB 93, (Everlight Chemical Industrial Corporation, Taipei, Taiwan), and (b) the UV absorber containing three types of hydroxyphenyl-benzotriazole (BTZ): commercial product EVERSORB 80 (Everlight Chemical Industrial Corporation, Taipei, Taiwan).

\subsection{Painting of Wood Surfaces with Coatings}

Before painting, the spruce samples were conditioned for $24 \mathrm{~h}$ at $20 \pm 2{ }^{\circ} \mathrm{C}$ after plasma modification. This downtime was chosen exactly because with prolongation significant chemical changes in the plasma modified wood surfaces can occur, following by decreases in their hydrophilicity and wettability (see Section 2.3), [45,51], and also certainly in their adhesion with coatings. The pneumatic spraying technology was used for the coating's application in three layers-each layer in an amount of $150 \pm 10 \mathrm{~g}$ per $\mathrm{m}^{2}$ of the wood surface. The second layer and the third layer of coatings were implemented after a $24 \mathrm{~h}$ intermission needed for the drying and curing of the previous layer applied to the wood surface and for its subsequent sanding with 240 grit sandpaper.

\subsection{Weathering of Coated Wood}

The 1 week artificial weathering of coated spruce samples was performed in the Q-SUN Xe-1-S Xenotest (Q-Lab Corporation, Westlake, OH, USA). It took place in accordance with the modified version of standard EN 927-6 [52], i.e., $24 \mathrm{~h}$ conditioning of samples at $45^{\circ} \mathrm{C}$ and then 48 subcycle steps-each lasting $3 \mathrm{~h}$ (2.5 h UV-radiation and then $0.5 \mathrm{~h}$ water spraying). These changes to [52] existed: Xenon lamps instead of fluorescent UV lamps; irradiance at $340 \mathrm{~nm}$ set to $0.55 \mathrm{~W} \cdot \mathrm{m}^{-2} \cdot \mathrm{nm}^{-1}$ instead of $0.89 \mathrm{~W} \cdot \mathrm{m}^{-2} \cdot \mathrm{nm}^{-1}$; the temperature on the black panel at $50^{\circ} \mathrm{C}$ instead of $60^{\circ} \mathrm{C}$.

The outdoor weathering of coated samples took place from May 122018 for periods of 0, 14, 28, and 42 weeks. It was performed in accordance with the standard EN 927-3 [53], at a slope of $45^{\circ}$ in metal stands oriented to the South, located in the industrial town of Zvolen, Slovakia, at $300 \mathrm{~m}$ above sea level. The testing area is characterized by many foggy days, smog, and high-temperature differences between summer (to $35^{\circ} \mathrm{C}$ ) and winter (to $-25^{\circ} \mathrm{C}$ ). Mean climatic conditions in this area were as follows: a temperature of $9.4{ }^{\circ} \mathrm{C}$; a relative air humidity of $83 \%$; water precipitation of $700 \mathrm{~mm} /$ year; and sun irradiation of $1100 \mathrm{kWh} / \mathrm{m}^{2}$.

\subsection{Adhesion between Coatings and Wood}

The adhesion strength between the individual coating types and the individually pre-treated/modified spruce samples was determined with the pull-off test for adhesion in accordance with the standard EN ISO 4624 [54], using the PosiTest AT-M Adhesion Tester instrument (DeFelsko, Ogdensburg, NY, USA). A bond connection between the surface of the coated spruce sample and the steel-roller dolly with a diameter of $20 \mathrm{~mm}$ was made by two-component epoxy resin. The pull-off test tensile strength method measures the tensile force perpendicular to the phase interface "coating-wood" system, requiring the tearing off of the steel-roller from the coated spruce sample, at which the failures could occur either in the weakest interface "coating-wood" (usually typical in this work), or in the weakest component "coating" or "wood". 


\subsection{Statistical Analysis}

The measured data of the adhesion strength were for individual groups of coated spruce samples evaluated on the basis of mean values and standard deviations. The effects of the HALS and BTZ UV-additives, added to coatings in concentrations (C) from 0 to $1 \mathrm{wt} . \%$, were analyzed by the linear correlation "Adhesion $=\mathrm{a}+\mathrm{b} \times \mathrm{C}^{\text {". }}$. The effect of the outdoor weathering prolongation $(\tau)$ from 0 to 42 weeks was analyzed by the exponential correlation "Adhesion $=\mathrm{a}+\mathrm{b} \times \exp (\mathrm{k} \times \tau)$ ". Within all correlations were determined the coefficients of determination $\mathrm{R}^{2}$.

\section{Results and Discussion}

\subsection{Adhesion Evaluated at Artificial Weathering}

From the first experiment, connected with the artificial weathering of coated spruce samples, it is evident that the adhesion strength of the acrylic and alkyd coatings to the Norway spruce wood surfaces was not significantly influenced by the presence of the HALS and BTZ UV-additives in coatings in a range of concentration (C) from 0 to $1 \mathrm{wt} . \%$. For example, for samples modified with plasma, the linear

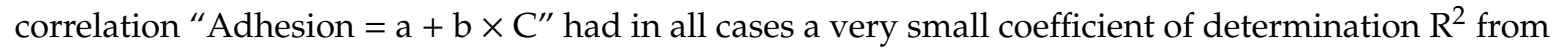
0.001 to 0.151 (Table 1). A similar result was obtained for the natural (plasma un-modified) samples.

Table 1. No effect of the hindered amine light stabilizer (HALS) and hydroxyphenyl-benzotriazoles (BTZ) used in the role of UV-additives on the adhesion strength between the coating (acrylic or alkyd) and the plasma modified Norway spruce wood-evaluation at none and 1 week artificial weathering-confirmed by the small coefficients of determination $\mathrm{R}^{2}$ from 0.001 to 0.151 for the linear correlations "Adhesion $=\mathrm{a}+\mathrm{b} \times \mathrm{C}^{\prime}$.

\begin{tabular}{|c|c|c|c|c|}
\hline \multirow{3}{*}{$\begin{array}{c}\text { UV-Additive } \\
\text { C (wt.\%) }\end{array}$} & \multicolumn{4}{|c|}{ Adhesion between Coatings and Plasma Modified Wood (MPa) } \\
\hline & \multicolumn{2}{|c|}{ None Weathering } & \multicolumn{2}{|c|}{ 1-Week Weathering in Xenotest } \\
\hline & Acrylic & Alkyd & Acrylic & Alkyd \\
\hline \multicolumn{5}{|l|}{ HALS } \\
\hline 0 & $2.90(0.39)$ & $2.92(0.29)$ & $2.13(0.31)$ & $2.43(0.28)$ \\
\hline 0.25 & $3.20(0.44)$ & $2.70(0.25)$ & $2.62(0.29)$ & $2.01(0.24)$ \\
\hline 0.5 & $2.80(0.31)$ & $2.43(0.38)$ & $2.35(0.37)$ & $2.20(0.34)$ \\
\hline 1.0 & $2.93(0.38)$ & $2.47(0.42)$ & $2.30(0.41)$ & $2.32(0.24)$ \\
\hline \multicolumn{5}{|c|}{ "Adhesion $=a+b \times C "$} \\
\hline a & 2.99 & 2.84 & 2.29 & 2.27 \\
\hline $\mathrm{b}$ & -0.08 & -0.47 & 0.09 & -0.03 \\
\hline $\mathrm{R}^{2}$ & 0.002 & 0.105 & 0.032 & 0.027 \\
\hline \multicolumn{5}{|l|}{ BTZ } \\
\hline 0 & $2.90(0.39)$ & $2.92(0.29)$ & $2.13(0.31)$ & $2.43(0.28)$ \\
\hline 0.25 & $2.77(0.55)$ & $2.73(0.31)$ & $2.33(0.30)$ & $2.30(0.28)$ \\
\hline 0.5 & $2.74(0.48)$ & $2.70(0.32)$ & $2.37(0.47)$ & $2.43(0.42)$ \\
\hline 1.0 & $3.03(0.63)$ & $2.97(0.24)$ & $2.47(0.41)$ & $2.27(0.22)$ \\
\hline \multicolumn{5}{|c|}{ "Adhesion $=a+b \times C "$} \\
\hline a & 2.79 & 2.77 & 2.23 & 2.38 \\
\hline $\mathrm{b}$ & 0.16 & 0.13 & 0.29 & -0.08 \\
\hline $\mathrm{R}^{2}$ & 0.002 & 0.001 & 0.151 & 0.023 \\
\hline
\end{tabular}

Notes: the mean value is from 6 measurements, i.e., from 3 replicates with a different mode of fungicidal pre-treatment (none, $\mathrm{H}_{3} \mathrm{BO}_{3}$, or benzalkonium chloride (BAC)), testing each replicate on 2 places. The standard deviation is in parentheses. The coefficient of determination $R^{2}$ of the linear correlation (Adhesion $=a+b \times C$ ) was determined from 24 values, i.e., 4 concentrations (C) of the UV-additive in the coating by 6 measurements.

The decrease in the adhesion strength between coatings and spruce samples due to the 1 week artificial weathering in Xenotest is documented by a drop in the parameter " $\mathrm{a}$ " in the linear correlations from 2.99-2.77 MPa to 2.38-2.23 MPa (Table 1). Analyzing the un-weathered samples, the acrylic and alkyd coatings - containing various amounts of the HALS or BTZ UV-additives-had a comparable 
adhesion strength with the spruce samples, as is documented by comparable values of the parameter "a" in the linear correlations, i.e., 2.99 or 2.79 MPa for acrylic coatings and 2.84 or 2.77 MPa for alkyd coatings (Table 1 ).

The impact of the HALS and BTZ UV-additives on the adhesion strength between coatings and plasma modified spruce wood was also analyzed as by the complex linear correlations "Adhesion $=\mathrm{a}+\mathrm{b} \times \mathrm{C}$ " (Figure 2). For both UV-additive types, a comparable parameter "a" $(2.60$ or $2.54 \mathrm{MPa})$ was determined, together with a very small and opposite parameter " $\mathrm{b}$ " $(-0.123$ or $0.122 \mathrm{MPa}$ ), and with very small values of the coefficient of determination " $\mathrm{R}^{2}=0.01$ " and $p>0.1$. These results confirm that the adhesion strength of the acrylic and alkyd coatings to the Norway spruce wood samples was not influenced by the presence of the UV-additives in the coatings.

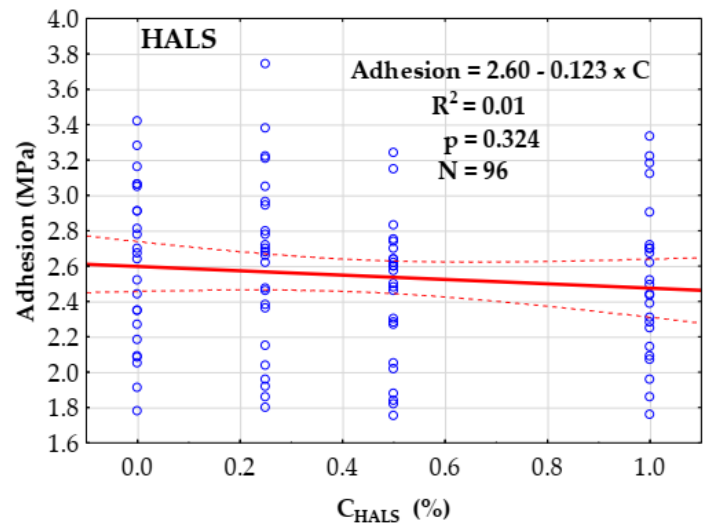

(a)

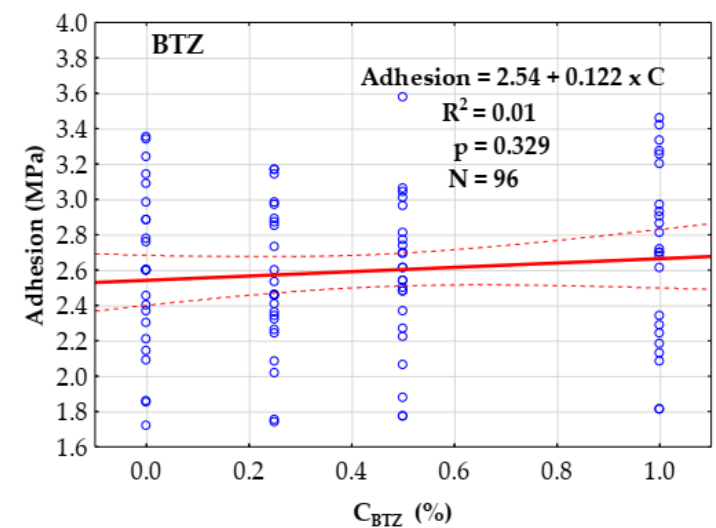

(b)

Figure 2. No effect of the UV-additives (a) HALS and (b) BTZ on the adhesion strength between the coatings and the plasma modified Norway spruce wood-confirmed by the small coefficient of determination $\mathrm{R}^{2}$ equal to 0.01 and $p>0.1$ for the linear correlations. Notes: the summary effect of UV-additives at the defined concentrations $(C=0,0.25,0.5$, or $1 \mathrm{wt} . \%)$ is from 24 data measured for 6 replicates of 2 coating types "acrylic and alkyd" and 2 weathering modes "none and 1 week in Xenotest". The coefficient of determination R2 of the linear correlation (Adhesion $=a+b \times C$ ) was determined from 96 values, i.e., from 24 values for one concentration of the UV-additive multiplied by 4 concentrations.

\subsection{Adhesion Evaluated at Outdoor Weathering}

The second experiment with the un-weathered and also with the 14 week, 28 week, and 42 week outdoor weathered coated spruce samples obtained other findings related to the adhesion strength.

The time prolongation $(\tau)$ of the outdoor weathering from 0 to 42 weeks caused in all cases (i.e., for three modes of fungicidal pre-treatment of wood; for two modes of plasma modification of wood; for two coating types) a significant decrease in the adhesion strength between the coatings and the wood surfaces, in summary from 3.01-2.12 MPa to 1.81-1.20 MPa (Tables 2-4, Figure 3). This knowledge was confirmed by the exponential correlations "Adhesion $=\mathrm{a}+\mathrm{b} \times \exp (\mathrm{k} \times \tau)$ " with high values of the coefficient of determination $R^{2}$ : (a) taking into account the different fungicidal pre-treatments of wood, the $R^{2}$ ranged from 0.903 to 0.997 (Tables 2-4), and (b) without taking into account the different fungicidal pre-treatments of wood, i.e., at the summary evaluation of the experiments when only the effects of coating type "acrylic or alkyd" and the plasma mode of wood modification "without or with" were taken into account, the $\mathrm{R}^{2}$ ranged from 0.827 to 0.991 (Figure 3). 
Table 2. The significant negative effects of outdoor weathering on the adhesion strength between the coating (acrylic or alkyd) and the native Norway spruce wood-subjected to or not subjected to plasma modification.

\begin{tabular}{ccccc}
\hline \multirow{2}{*}{$\begin{array}{c}\text { Weathering } \\
\boldsymbol{\tau} \text { (Weeks) }\end{array}$} & \multicolumn{4}{c}{ Adhesion (MPa) } \\
\cline { 2 - 5 } & \multicolumn{2}{c}{ Native-Plasma Wood } & \multicolumn{2}{c}{ Native-Natural Wood } \\
\cline { 2 - 5 } & Acrylic & Alkyd & Acrylic & Alkyd \\
\hline 0 & $2.82(0.58)$ & $2.75(0.33)$ & $2.20(0.51)$ & $2.58(0.31)$ \\
14 & $1.87(0.37)$ & $2.18(0.50)$ & $1.64(0.65)$ & $1.99(0.38)$ \\
28 & $1.37(0.39)$ & $1.53(0.38)$ & $1.44(0.40)$ & $1.84(0.22)$ \\
42 & $1.31(0.21)$ & $1.51(0.42)$ & $1.20(0.22)$ & $1.42(0.29)$ \\
“Adhesion $=\mathbf{a}+\mathbf{b} \times \mathbf{e x p}(\mathbf{k} \times \boldsymbol{\tau})^{\prime \prime}$ & & & \\
$\mathrm{a}$ & 1.165 & 1.119 & 1.019 & 0.689 \\
$\mathrm{~b}$ & 1.661 & 1.653 & 1.173 & 1.866 \\
$\mathrm{k}$ & -0.065 & -0.039 & -0.041 & -0.021 \\
$\mathrm{R}^{2}$ & 0.995 & 0.965 & 0.991 & 0.966 \\
\hline
\end{tabular}

Notes: the mean value is from 16 measurements (2 UV-additives "HALS or BTZ"; 4 concentrations of each UV-additive "0, $0.25,0.5$ and 1 wt. $\% " ; ~ 2$ testing places on replicate). This mode of evaluation could be used on the basis of the knowledge that the adhesion strength was not significantly influenced by the UV-additive, i.e., by its type and concentration in the coating (see Section 3.1; Table 1 and Figure 2). The standard deviation is in the parentheses. A significant drop in the adhesion at the prolonged time of weathering $(\tau)$ was evaluated by the exponential equation "Adhesion $=\mathrm{a}+\mathrm{b} \times \exp (\mathrm{k} \times \tau)$ " from 64 values, with $\mathrm{R}^{2}$ always above 0.95 .

Table 3. The significant negative effect of outdoor weathering on the adhesion between the coating (acrylic or alkyd) and the Norway spruce wood pre-treated with fungicide $\mathrm{H}_{3} \mathrm{BO}_{3}$ - subjected to or not subjected to plasma modification.

\begin{tabular}{ccccc}
\hline \multirow{2}{*}{$\begin{array}{c}\text { Weathering } \\
\boldsymbol{\tau} \text { (Weeks) }\end{array}$} & \multicolumn{4}{c}{ Adhesion (MPa) } \\
\cline { 2 - 5 } & $\mathbf{H}_{\mathbf{3}} \mathbf{B O}_{3}$-Plasma Wood & \multicolumn{2}{c}{$\mathbf{H}_{3} \mathbf{B O}_{3}$-Natural Wood } \\
\cline { 2 - 5 } Acrylic & Alkyd & Acrylic & Alkyd \\
\hline 0 & $2.90(0.44)$ & $2.77(0.34)$ & $2.12(0.43)$ & $2.36(0.42)$ \\
14 & $1.77(0.47)$ & $2.29(0.38)$ & $1.45(0.46)$ & $1.75(0.23)$ \\
28 & $1.32(0.24)$ & $1.87(0.23)$ & $1.40(0.14)$ & $1.56(0.28)$ \\
42 & $1.30(0.28)$ & $1.74(0.19)$ & $1.24(0.13)$ & $1.55(0.14)$ \\
“Adhesion $=\mathbf{a}+\mathbf{b} \times \mathbf{e x p}(\mathbf{k} \times \boldsymbol{\tau})$ & & & \\
$\mathrm{A}$ & 1.211 & 1.374 & 1.279 & 1.522 \\
$\mathrm{~B}$ & 1.692 & 1.405 & 0.838 & 0.839 \\
$\mathrm{~K}$ & -0.083 & -0.034 & -0.103 & -0.095 \\
$\mathrm{R}^{2}$ & 0.997 & 0.993 & 0.980 & 0.998 \\
\hline
\end{tabular}

Notes: the mean value is from 16 measurements (see the first note in Table 2). The standard deviation is in the parentheses. A significant drop in the adhesion at the prolonged time of weathering $(\tau)$ was evaluated by the exponential equation "Adhesion $=\mathrm{a}+\mathrm{b} \times \exp (\mathrm{k} \times \tau)$ " from 64 values, with $\mathrm{R}^{2}$ always above 0.95 .

Another basic finding was obtained for the plasma modified spruce samples in the un-weathered state. Their adhesion strength with the acrylic and alkyd coatings was higher in comparison to the natural (plasma un-modified) spruce samples: i.e., the adhesion strength of the plasma modified wood was on average higher by $16.5 \%$ in testing the native chemically un-pre-treated wood ( 2.785 to $2.39 \mathrm{MPa})$, by $26.6 \%$ in testing the $\mathrm{H}_{3} \mathrm{BO}_{3}$ pre-treated wood ( 2.835 to $2.24 \mathrm{MPa}$ ) and by $13.6 \%$ in testing the BAC pre-treated wood (2.845 to $2.505 \mathrm{MPa}$ ) - (Tables 2-4). The plasma modification of the wood surfaces had a more positive effect on the adhesion strength of the acrylic coatings, increased by $20.5 \%$ (from 6.5 to $7.83 \mathrm{MPa}$ ), than the alkyd coatings, increased by 5.5\% (from 7.77 to $8.2 \mathrm{MPa}$ ). This result can be explained by the better wettability of the hydrophilic plasma modified spruce surfaces with more polar water-borne acrylic coatings (see Section 3.3). However, as a result of the outdoor weathering, the positive effect of plasma on the adhesion strength disappeared in most cases (Tables 2-4), which was 
more apparent for samples painted with acrylic coatings, which manifested less durable to sunlight, water and other weathering agents (Figure 3).

Table 4. The significant negative effect of the outdoor weathering on the adhesion between the coating (acrylic or alkyd) and the Norway spruce wood pre-treated with fungicide BAC — subjected to or not subjected to plasma modification.

\begin{tabular}{ccccc}
\hline \multirow{2}{*}{$\begin{array}{c}\text { Weathering } \\
\boldsymbol{\tau} \text { (Weeks) }\end{array}$} & \multicolumn{4}{c}{ Adhesion (MPa) } \\
\cline { 2 - 5 } & BAC-Plasma Wood & \multicolumn{2}{c}{ BAC-Natural Wood } \\
\cline { 2 - 5 } & Acrylic & Alkyd & Acrylic & Alkyd \\
\hline 0 & $3.01(0.42)$ & $2.68(0.52)$ & $2.18(0.34)$ & $2.83(0.56)$ \\
14 & $1.75(0.37)$ & $2.23(0.48)$ & $1.91(0.47)$ & $2.43(0.50)$ \\
28 & $1.28(0.20)$ & $2.02(0.22)$ & $1.50(0.19)$ & $1.36(0.38)$ \\
42 & $1.26(0.27)$ & $1.81(0.20)$ & $1.53(0.35)$ & $1.37(0.32)$ \\
“Adhesion $=\mathbf{a}+\mathbf{b} \times \mathbf{e x p}(\mathbf{k} \times \boldsymbol{\tau}){ }^{\prime \prime}$ & & & \\
$\mathrm{A}$ & 1.174 & 1.548 & 1.282 & 0.036 \\
$\mathrm{~B}$ & 1.839 & 1.126 & 0.916 & 2.860 \\
$\mathrm{~K}$ & -0.086 & -0.034 & -0.037 & -0.020 \\
$\mathrm{R}^{2}$ & 0.997 & 0.996 & 0.932 & 0.903 \\
\hline
\end{tabular}

Notes: the mean value is from 16 measurements (see the first note in Table 2). The standard deviation is in the parentheses. A significant drop in the adhesion at the prolonged time of weathering $(\tau)$ was evaluated by the exponential equation "Adhesion $=\mathrm{a}+\mathrm{b} \times \exp (\mathrm{k} \times \tau)$ " from 64 values, with $\mathrm{R}^{2}$ above 0.95 or 0.90 . 


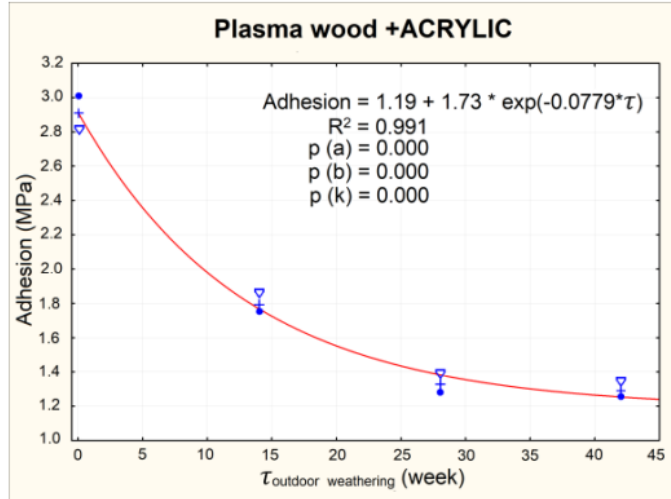

(a)

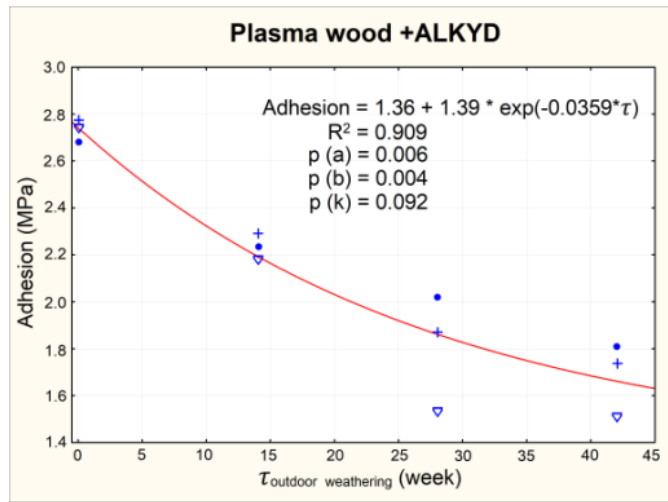

(c)

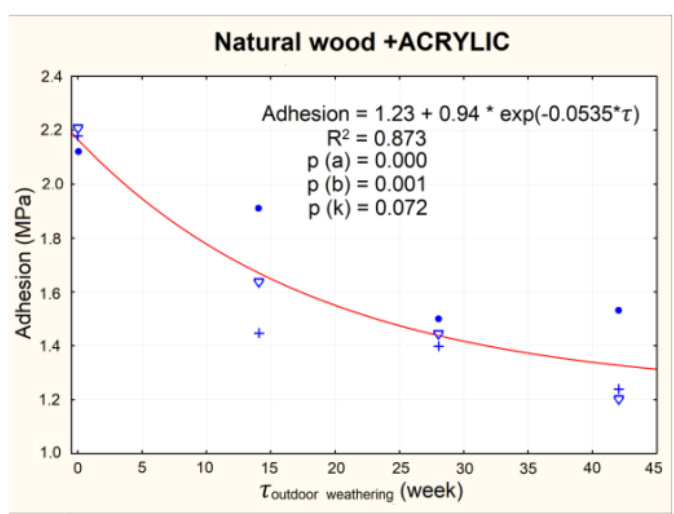

(b)

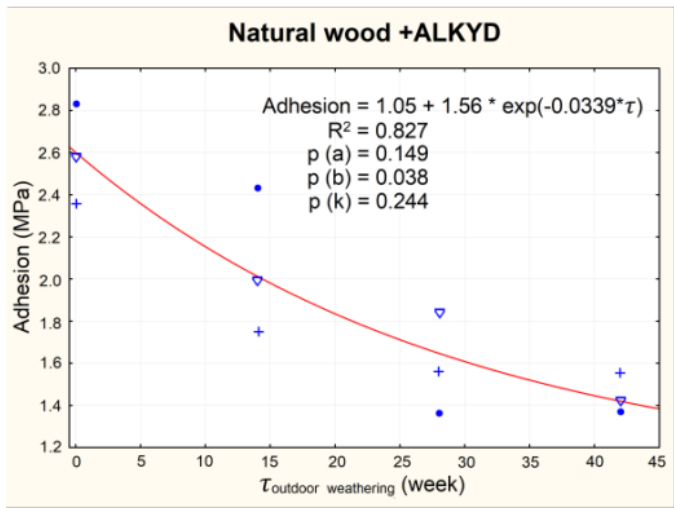

(d)

Figure 3. The summary evaluation-negative effects of the outdoor weathering prolongation (from 0 to 42 weeks) on the adhesion strength between the acrylic $(\mathbf{a}, \mathbf{b})$ or alkyd $(\mathbf{c}, \mathbf{d})$ coatings and the plasma modified spruce wood $(\mathbf{a}, \mathbf{c})$ or the natural spruce wood $(\mathbf{b}, \mathbf{d})$. Notes: each point in the graphs represents the mean value of the adhesion from 16 measurements-performed on 2 places of 8 different replicate types ( $2 \mathrm{UV}$-additives used in 4 concentrations). The coefficients of determination $\mathrm{R}^{2}$ for the exponential equation "Adhesion $=\mathrm{a}+\mathrm{b} \times \exp (\mathrm{k} \times \tau)$ " (evaluating 12 mean values, i.e., 3 fungicidal pre-treatments: $\nabla$ native wood $+\mathrm{H}_{3} \mathrm{BO}_{3}$ pre-treated wood, $\bullet$ BAC pre-treated wood, multiplied by the 4 outdoor weathering times) were high, from 0.827 to 0.991 — confirming they have significance.

The presence of fungicides $\mathrm{H}_{3} \mathrm{BO}_{3}$ and $\mathrm{BAC}$ in spruce samples did not affect the adhesion strength of acrylic and alkyd coatings to their surfaces. In the complex evaluation-taking into account two coating types, two modes of wood modification with plasma, and the four outdoor weathering times - the average adhesion strength was comparable for the native wood (1.853 MPa), the wood pre-treated with $\mathrm{H}_{3} \mathrm{BO}_{3}(1.837 \mathrm{MPa})$, and the wood pre-treated with $\mathrm{BAC}(1.947 \mathrm{MPa})$ (averages calculated from Tables 2-4).

Comprehensively, comparing the adhesion strength of acrylic and alkyd coatings to spruce samples-i.e., for the four outdoor weathering times $(0,14,28,42$ weeks), taking into account three modes of fungicidal pre-treatment of wood and also two modes of plasma modification of wood surfaces - the adhesion strength of acrylic coatings was partly lower (1.74 $\mathrm{MPa})$ than alkyd coatings (2.016 MPa) (averages calculated from Tables 2-4). The adhesion strength of tested coating types comparably worsened with the time prolongation of the outdoor weathering. For the coated natural (plasma un-modified) spruce samples, the adhesion decreased less using acrylic coatings (by 38.92\%, from 2.166 to $1.323 \mathrm{MPa}$ ) than using alkyd coatings (by $44.13 \%$, from 2.59 to $1.447 \mathrm{MPa}$ ). On the contrary, for the coated plasma modified wood, the adhesion strength when using the acrylic coatings decreased more (by $55.67 \%$, from 2.91 to $1.29 \mathrm{MPa}$ ) than when using the alkyd coatings (by $38.22 \%$, from 2.73 to $1.687 \mathrm{MPa}$-_(Figure 3, and Tables 2-4). 


\subsection{Opinions of Some Researchers on the Adhesion of Coatings to Wood Surfaces under the Influence of} Modification and Weathering Impacts

Several studies have reported that the adhesion strength between an individual coating type and an individual wood species depends first of all on the chemical and physical characteristics of the contacting materials and the aging conditions of coated wood products.

Moya et al. [14] found that the addition of $\mathrm{TiO}_{2}$ nanoparticles, used as an UV-additive, to a water-based coating in the amount of $1 \%$ or $1.5 \%$ did not significantly affect the adhesion strength of the modified coating to seven (from nine tested) tropical wood species. This result is in line with our results concerning the un-significant impact of HALS and BTZ UV-additives in coatings on the adhesion strength (see Section 3.1).

Rehn et al. [39], Acda et al. [41] and Wolkenhauer et al. [55] found that the initial activation of wood surfaces with the atmospheric pressure plasma improved the paint adhesion and bondability by up to $30 \%$. Their conclusions are in accordance with our results related to the water-borne acrylic coatings (see Section 3.2).

Riedl et al. [51] demonstrated that with prolonging plasma modification of maple sugar wood, its wettability (dispersive adhesion) improved more than its adhesion strength with the UV-cured polyurethane/polyacrylate coating. This is because, in addition to the free surface energy (dispersive adhesion), a number of other phenomena drive the adhesion dynamics, including surface roughness (mechanical adhesion), the formation of chemical bonds (chemical adhesion), presence of electrical discharges (electrostatic adhesion), and solubility of the coating (diffusive adhesion). Jablonský et al. [45] recommend applying water-borne coating systems on wood surfaces right after the plasma treatment, when the activated wood surface with a higher portion of polar functional groups adopts the highest degree of hydrophilicity. This is in accordance with experiments performed by Král et al. [47], where the X-ray photoelectron spectroscopy study confirmed that in beech wood surfaces were created polar functional groups at exposure to atmospheric pressure plasma, which have a positive effect on the wettability.

Avramidis et al. [56] found a positive effect of plasma on the adhesion between polyvinyl acetate (PVAc) glue and beech wood pre-treated with synthetic waxes or montan-ester waxes, because a force in the sensitive peel test increased by about $50-60 \%$. This result is not entirely in agreement with the results of our experiment, where the plasma modification of spruce wood pre-treated with fungicide not unequivocally increased the adhesion of acrylic and alkyd coatings (see Tables 2-4). In the un-weathered state of the coated samples, the combined effect of fungicide and plasma on the adhesion strength was positive with the application of water-borne acrylic coatings (increased by $2.8 \%$ for boric acid, or by $6.7 \%$ for BAC); however, with the application of alkyd coatings, it was either negligibly positive (increased by $0.7 \%$ for boric acid) or even negative (drop by $2.55 \%$ for BAC). The different results achieved by us and by [56] can be explained by the non-polar characteristics of waxes and vice versa by the high polarity of fungicides used in our work; however, some other factors could play a role as well.

Moghaddam et al. [49] also searched the combined "chemical substance and plasma" effect on the wettability characteristics of wood surfaces. They created a thin transparent superhydrophobic layer on pine veneer surfaces from $\mathrm{TiO}_{2}$ with the liquid flame spray technique and following the deposition of plasma polymerized perfluoro-hexane or hexamethyldisiloxane. The hydrophobic effect of this approach was stable even after repeated wetting cycles and was higher compared to that of plasma modified surfaces.

\section{Conclusions}

- The HALS and BTZ UV-additives applied to coatings in concentrations from 0 to $1 \mathrm{wt} . \%$ had no significant positive or negative effects on the adhesion strength between the acrylic or alkyd coatings and the Norway spruce wood. 
- Before the outdoor weathering, alkyd coatings had a slightly better adhesion strength to spruce surfaces by $4.7 \%$ (in summary $2.66 \mathrm{MPa}$ : to natural wood 2.59 MPa and to plasma modified wood $2.73 \mathrm{MPa}$ ) than acrylic coatings (in summary $2.54 \mathrm{MPa}$ : to natural wood $2.17 \mathrm{MPa}$ and to plasma modified wood 2.91 MPa). After 42 weeks of outdoor weathering, the adhesion strength of alkyd coatings in comparison to acrylic coatings was better by $19.8 \%$, as in summary the adhesion strength of alkyd coatings dropped to $1.57 \mathrm{MPa}$ while for acrylic coatings the adhesion strength dropped to $1.31 \mathrm{MPa}$. Therefore, the acrylic coatings were less durable to sunlight, water and other weathering agents than the alkyd ones.

- The fungicidal pre-treatment of spruce samples with boric acid $\left(\mathrm{H}_{3} \mathrm{BO}_{3}\right)$ or benzalkonium chloride (BAC) did not affect the adhesion of coatings to wood surfaces. At a summary evaluation, i.e., taking into account two coating types "acrylic and alkyd", two modes of plasma modification of wood surfaces "natural wood and plasma wood", and four outdoor weathering times " 0,14 , 28 and 42 weeks", the average adhesion strength between wood surfaces and coatings was comparable for the native wood $(1.85 \mathrm{MPa})$, the wood pre-treated with $\mathrm{H}_{3} \mathrm{BO}_{3}(1.84 \mathrm{MPa})$, and the wood pre-treated with BAC (1.95 MPa).

- In the un-weathered state, the plasma modified wood had better adhesion with the coatings than the natural wood, with apparently more adhesion with acrylic coatings (increased by $20.5 \%$, from 6.5 to $7.83 \mathrm{MPa}$ ) than with alkyd coatings (increased by only $5.5 \%$, from 7.77 to $8.2 \mathrm{MPa}$ ). However, after the outdoor weathering of the coated spruce samples, the positive effect of plasma disappeared, mainly for the acrylic coatings (see point two in conclusions).

- Prolongation of the outdoor weathering from 0 to 42 weeks was associated with a significant negative exponential impact on the adhesion strength between used coatings and spruce surfaces, at which it, in summary, decreased from 3.01-2.12 MPa to 1.81-1.20 MPa.

Author Contributions: Conceptualization, L.R.; methodology, L.R.; software, L.R. and M.Š.; validation, L.R. and R.T.; formal analysis, L.R. and M.Š.; investigation, L.R., R.T. and M.Š.; resources, L.R. and M.Š.; data curation, L.R. and M.Š.; writing—original draft preparation, L.R.; writing—review and editing, L.R. and R.T.; visualization, L.R. and M.S.; supervision, L.R.; project administration, L.R.; funding acquisition, L.R. All authors have read and agreed to the published version of the manuscript.

Funding: This work was supported by the Slovak Research and Development Agency under contract no. APVV-17-0583.

Acknowledgments: We would like to thank the company Chemolak Smolenice Ltd., Slovakia for providing part of the materials for this research.

Conflicts of Interest: The authors declare no conflict of interest.

\section{References}

1. Kataoka, Y.; Kiguchi, M.; Williams, R.S.; Evans, P.D. Violet light causes photodegradation of wood beyond the zone affected by ultraviolet radiation. Holzforschung 2007, 61, 23-27. [CrossRef]

2. Reinprecht, L.; Vidholdová, Z.; Iždinský, J. Bacterial and mold resistance of selected tropical wood species. BioResources 2020, 15, 5198-5209.

3. Aloui, F.; Ahajii, A.; Irmouili, Y.; Goerge, B.; Charrier, B.; Merlin, A. Inorganic UV absorbers for the photostabilisation of wood-clearcoating systems: Comparison with organic UV absorbers. Appl. Surf. Sci. 2007, 253, 3737-3745. [CrossRef]

4. Reinprecht, L.; Baculák, J.; Pánek, M. Natural and accelerated ageing of pains for wooden windows. Acta Fac. Xylologiae Zvolen 2011, 53, 21-31.

5. Forsthuber, B.; Schaller, C.; Grüll, G. Evaluation of the photo stabilizing efficiency of clear coatings comprising organic UV absorbers and mineral UV screeners on wood surfaces. Wood Sci. Technol. 2013, 47, 281-297. [CrossRef]

6. Poubel, D.D.; Garcia, R.A.; Lelis, R.C.C.; Riedl, B. Effect of $\mathrm{ZnO}$ nanoparticles on UV resistance of the heat-treated pine wood. Sci. For. 2017, 45, 49-62. 
7. Pánek, M.; Oberhofnerová, E.; Zeidler, A.; Šedivka, P. Efficacy of hydrophobic coatings in protecting oak wood surfaces during accelerated weathering. Coatings 2017, 7, 172. [CrossRef]

8. Iždinský, J.; Reinprecht, L.; Nosál, E. Antibacterial efficiency of silver and zinc-oxide nanoparticles in acrylate coating for surface treatment of wooden composites. Wood Res. 2018, 63, 365-372.

9. Pánek, M.; Reinprecht, L. Colour stability and surface defects of naturally aged wood treated with transparent paints for exterior constructions. Wood Res. 2014, 59, 421-430.

10. Ozgenc, O.; Hiziroglu, S.; Yildizc, U.C. Weathering properties of wood species treated with different coating applications. BioResources 2012, 7, 4875-4888. [CrossRef]

11. Teacă, C.A.; Roşu, D.; Bodîrlău, R.; Roşu, L. Structural changes in wood under artificial UV light irradiation determined by FTIR spectroscopy and color measurements-A brief review. BioResources 2013, 8, 1478-1507. [CrossRef]

12. Cristea, M.V.; Riedl, B.; Blanchet, P. Enhancing the performance of exterior waterborne coatings for wood by inorganic nanosized UV absorbers. Prog. Organ. Coat. 2010, 69, 432-441. [CrossRef]

13. Blanchard, V.; Blanchet, P. Color stability for wood products during use: Effects of inorganic nanoparticles. BioResources 2011, 6, 1219-1229.

14. Moya, R.; Rodríguez-Zúñiga, A.; Vega-Baudrit, J.; Puente-Urbina, A. Effects of adding TiO2 nanoparticles to a water-based varnish for wood applied to nine tropical woods of Costa Rica exposed to natural and accelerated weathering. J. Coat. Technol. Res. 2017, 14, 141-152. [CrossRef]

15. Schaller, C.; Rogez, D. New approaches in wood coating stabilization. J. Coat. Technol. Res. 2007, 4, 401-409. [CrossRef]

16. Forsthuber, B.; Grüll, G. The effect of HALS in the prevention of photo-degradation of acrylic clear topcoats and wooden surfaces. Polym. Degrad. Stabil. 2010, 95, 746-755. [CrossRef]

17. Samyn, P.; Stanssens, D.; Paredes, A.; Becker, G. Performance of organic nanoparticle coatings for hydrophobization of hardwood surfaces. J. Coat. Technol. Res. 2014, 11, 461-471. [CrossRef]

18. Meijer, M.D. Review on the durability of exterior wood coatings with reduced VOC-content. Prog. Organ. Coat. 2001, 43, 217-225. [CrossRef]

19. Grüll, G.; Tscherne, F.; Spitaler, I.; Forsthuber, B. Comparison of wood coating durability in natural weathering and artificial weathering using fluorescent UV-lamps and water. Eur. J. Wood Wood Prod. 2014, 72, 367-376. [CrossRef]

20. Reinprecht, L. Fungicides for Wood Protection-World Viewpoint and Evaluation/Testing in Slovakia. In Fungicides; Carisse, O., Ed.; InTech: Rijeka, Croatia, 2010; pp. 95-122.

21. Weththimuni, M.L.; Capsoni, D.; Malagodi, M.; Licchelli, L. Improving wood resistance to decay by nanostructured ZnO-based treatments. J. Nanomater. 2019, 2019, 6715756. [CrossRef]

22. Nejad, M. Coating Performance on Preservative Treated Wood. Ph.D. Thesis, Department of Forestry, University of Toronto, Toronto, ON, Canada, 2011; p. 154.

23. Daniels, T.; Hirsch, M.; McClelland, K.; Ross, A.; Williams, R.S. Clear exterior finishes: Finding the balance between aesthetics and durability. JCT Coat. Tech. 2004, 9, 42-48.

24. Williams, R.S.; Jourdain, C.; Daisey, G.; Springate, R.W. Wood properties affecting finish service life. J. Coat. Technol. 2000, 72, 35-42. [CrossRef]

25. Wagenführ, R. Holzatlas, 6th ed.; Fachbuchverlag: Leipzig, Germany, 2007; p. 816.

26. Tascioglu, C.; Yalcin, M.; Sen, S.; Akcay, C. Antifungal properties of some plant extracts used as wood preservatives. Int. Biodeterior. Biodegrad. 2013, 85, 23-28. [CrossRef]

27. Kúdela, J. Wetting of wood surface by a liquids of a different polarity. Wood Res. 2014, 59, 11-24.

28. Jankowska, A.; Boruszewski, P.; Drozdzek, M.; Rebkowski, B.; Kaczmarczyk, A.; Skowronska, A. The role of extractives and wood anatomy in the wettability and free surface energy of hardwoods. BioResources 2018, 13, 3082-3097. [CrossRef]

29. Zhang, H.; Kai, T.U.; Hou, Q.; Lin, H.; Quan, L.I. The physiological and biochemical mechanisms of Cinnamomum camphora xylem extracts inhibit wood-decay fungi. Wood Res. 2020, 65, 531-542. [CrossRef]

30. Reinprecht, L. Wood Deterioration, Protection and Maintenance, 1st ed.; John Wiley \& Sons Ltd.: Chichester, UK, 2016; p. 357.

31. Cheng, E.; Sun, X. Effects of wood-surface roughness, adhesive viscosity and processing pressure on adhesion strength of protein adhesive. J. Adhes. Sci. Technol. 2006, 20, 997-1017. [CrossRef] 
32. Kaygin, B.; Akgun, E. Comparison of conventional varnishes with nanolacke UV varnish with respect to hardness and adhesion durability. Int. J. Mol. Sci. 2008, 9, 476-485. [CrossRef]

33. Kúdela, J.; Liptáková, E. Adhesion of coating materials to wood. J. Adhes. Sci. Technol. 2012, 20, 875-895. [CrossRef]

34. Odrášková, M.; Rahel, J.; Zahoranová, A.; Tiňo, R.; Černák, M. Plasma activation of the wood surface by diffuse coplanar surface barrier discharge. Plasma Chem. Plasma Process. 2008, 28, 203-211. [CrossRef]

35. Viöl, W. Possibilities of cold plasma treatment at atmospheric pressure to modify wood surfaces and relevant applications. In Proceedings of the 18th International Conference on Surface Modification of Materials by Ion Beams, Wood and Organic Materials, Kusadasi, Turkey, 15-20 September 2013; Volume 9, p. 2013.

36. Nguyen, T.; Chen, W.; Cao, Y.; Wang, X.; Shi, S.; Chen, M.; Zhou, X.; Nguyen, Q. Improving bonding strength of oven-dried poplar veneers using atmospheric cold plasma treatment. BioResources 2018, 13, 1843-1851. [CrossRef]

37. Žigon, J.; Petrič, M.; Dahle, S. Dielectric barrier discharge (DBD) plasma treatment of lignocellulosic materials in air at atmospheric pressure for their improved wettability: A literature review. Holzforschung 2018, 72, 979-991. [CrossRef]

38. Hünnekens, B.; Avramidis, G.; Ohms, G.; Krause, A.; Viöl, W.; Militz, H. Impact of plasma treatment under atmospheric pressure on surface chemistry and surface morphology of extruded and injection-molded wood-polymer composites (WPC). Appl. Surf. Sci. 2018, 441, 564-574. [CrossRef]

39. Rehn, P.; Wolkenhauer, A.; Bente, M.; Förster, S.; Viöl, W. Wood surface modification in dielectric barrier discharges at atmospheric pressure. Surf. Coat. Technol. 2003, 174-175, 515-518. [CrossRef]

40. Wolkenhauer, A.; Avramidis, G.; Hauswald, E.; Militz, H.; Viöl, W. Sanding vs. plasma treatment of aged wood: A comparison with respect to surface energy. Int. J. Adhes. Adhes. 2009, 29, 18-22. [CrossRef]

41. Acda, M.N.; Devera, E.E.; Cabangon, R.J.; Ramos, H.J. Effects of plasma modification on adhesion properties of wood. Int. J. Adhes. Adhes. 2012, 32, 70-75. [CrossRef]

42. Avramidis, G.; Klarhöfer, L.; Maus-Friedrischs, W.; Militz, H.; Viöl, W. Influence of air plasma treatment at atmospheric pressure on wood extractives. Polym. Degrad. Stabil. 2012, 97, 469-471. [CrossRef]

43. Novák, I.; Chodák, I.; Sedliačik, J.; Vanko, V.; Matyašovský, J.; Šivová, M. Pre-treatment of beech wood by cold plasma. Forest. Wood Technol. 2013, 83, 288-291.

44. Reinprecht, L.; Tiňo, R.; Šomšák, M. Adhesion of coatings to plasma modified wood at accelerated weathering. In Proceedings of the European Conference on Wood Modification 2018 (ECWM9), Arnhem, The Netherlands, 17-18 September 2018; p. 54.

45. Jablonský, M.; Šmatko, L.; Botková, M.; Tino, R.; Šima, J. Modification of wood wettability (European Beech) by diffuse coplanar surface barrier discharge plasma. Cellul. Chem. Technol. 2014, 50, 41-48.

46. Potočńáková, L.; Hnilica, J.; Kudrle, V. Increase of wettability of soft- and hardwoods using microwave plasma. Int. J. Adhes. Adhes. 2013, 45, 125-131. [CrossRef]

47. Král, P.; Ráhel, J.; Stupavská, M.; Šrajer, J.; Klímek, P.; Mishra, K.P.; Wimmer, R. XPS depth profile of plasma-activated surface of beech wood (Fagus sylvatica) and its impact on polyvinyl acetate tensile shear bond strength. Wood Sci. Technol. 2015, 49, 319-330. [CrossRef]

48. Yousoo, H.; Manolach, S.O.; Denes, F.; Rowell, R.M. Cold plasma treatment on starch foam reinforced with wood fiber for its surface hydrophobicity. Carbohydr. Polym. 2011, 86, 1031-1037.

49. Moghaddam, S.M.; Heydari, G.; Tuominen, M.; Fielden, M.; Haapanen, J.; Mäkelä, M.J.; Wålinder, E.P.M.; Claesson, M.P.; Swerin, A. Hydrophobisation of wood surfaces by combining liquid flame spray (LFS) and plasma treatment: Dynamic wetting properties. Holzforschung 2016, 70, 527-537. [CrossRef]

50. EN ISO 4287. Geometrical Product Specifications (GPS). Surface Texture: Profile Method-Terms, Definitions and Surface Texture Parameters; European Committee for Standardization: Brussels, Belgium, 1997.

51. Riedl, B.; Angel, C.; Prégent, J.; Blanchet, P.; Stafford, L. Wood surface modification by atmospheric-pressure plasma and effect on waterborne coating adhesion. LignoCellulose 2013, 2, 292-306. [CrossRef]

52. EN 927-6. Paints and Varnishes. Coating Materials and Coating Systems for Exterior Wood. Part 6: Exposure of Wood Coatings to Artificial Weathering Using Fluorescent UV Lamps and Water; European Committee for Standardization: Brussels, Belgium, 2018.

53. EN 927-3. Paints and Varnishes. Coating Materials and Coating Systems for Exterior Wood. Part 3: Natural Weathering Test; European Committee for Standardization: Brussels, Belgium, 2012. 
54. EN ISO 4624. Paints and Varnishes. Pull-off Test for Adhesion; European Committee for Standardization: Brussels, Belgium, 2016.

55. Wolkenhauer, A.; Avramidis, G.; Hauswald, E.; Militz, H.; Viöl, W. Plasma treatment of wood-plastic composites to enhance their adhesion properties. J. Adhes. Sci. Technol. 2008, 22, 2025-2037. [CrossRef]

56. Avramidis, G.; Scholz, G.; Nothnick, E.; Militz, H.; Viöl, W.; Wolkenhauer, A. Improved bondability of wax-treated wood following plasma treatment. Wood Sci. Technol. 2011, 45, 359-368. [CrossRef]

Publisher's Note: MDPI stays neutral with regard to jurisdictional claims in published maps and institutional affiliations.

(C) 2020 by the authors. Licensee MDPI, Basel, Switzerland. This article is an open access article distributed under the terms and conditions of the Creative Commons Attribution (CC BY) license (http://creativecommons.org/licenses/by/4.0/). 